\title{
The Effects of Foreign Market Entry Strategies on Financial Performance of Listed Multinational Firms in Kenya
}

\author{
C. Smith, M. Ogutu, M. Munjuri, and J. Kagwe
}

\section{ABSTRACT}

The objective of this study was to establish the effects of foreign market entry strategies on the financial performance of listed multinational firms in Kenya. Internationalization theory was used as the theoretical foundation of the study. Empirical studies reviewed revealed that several studies had been done on the direct relationship between performance of multinational firms and their modes of entry into foreign firms. However, none of these studies focused on the financial performance of listed multinational firms. The study utilised a cross-sectional descriptive design. Secondary data collected from firms' annual reports and financial statements for a period of four years (2014 to 2017) was used. The firms' financial indicators of Sales Growth, Return on Equity, Return on Assets and Return on Capital Employed were employed to measure their performance. Franchising, exporting, wholly owned subsidiary and acquisitions were assessed as the entry strategies used by multinational firms. Data was collected from all the 62 listed multinational companies in Kenya and analysed using quantitative methods. This analysis was most preferred for data collected was quantitative in nature. The relationship between the independent and the dependent variable was tested using simple linear regression. The results show that the performance of multinational firms operating through franchises and as wholly owned subsidiaries as well as acquisitions was lower than the performance of multinationals operating as export companies. The study concludes that the mode of entry into foreign markets chosen by a firm significantly affected its financial performance in the said market. It is therefore recommended that multinational firms wishing to expand their operations globally to come up with long term strategies that have gone through rigorous scrutiny for the benefit of the firm. The study gave a contextual understanding of the internationalization theory. The theory managed to emphasize on reasons why multinational firms should expand their operations beyond their national boundaries. Actual ingredients for policy makers to undertake a well thought through policy formulation to fully understand the importance of choosing the right entry strategy was provided for in the results. Recommendations of the study are that a thorough marketing evaluation of the country of interest should be undertaken to ensure that proper measures are put in place for the selection of an entry strategy that will address the goals and objectives of a firm. The study also recommends that employees of a firm who are at the forefront in the internationalization process should be well informed and trained ahead of the firm's plans. Policy makers and advisories in countries are advised to streamline the processes of foreign firms' registration so to attract foreign investors.

Keywords: Foreign Market entry strategies, Financial Performance, Multinational firms, acquisition, joint-ventures, wholly owned subsidiaries, Franchising.

\section{INTRODUCTION}

The profit margins of firms in the developed markets has significantly reduced over the years due to their saturation, an argument posited by [21]. This has led to stiff competition in these markets and the need for firms to expand their operations and increase their global footprint in the international markets. More so, the need for multinational firms to reach foreign customers has gained popularity
Submitted: September 09, 2020

Published: June **, 2021

ISSN: $2507-1076$

DOI: $10.24018 /$ ejbmr.2021.6.3.517

C. Smith*

Ph.D. Candidate, University of Nairobi,

Kenya.

(csmith.lindsay@gmail.com)

M. Ogutu

Associate Professor, University of

Nairobi, Kenya.

(ogutum ${ }^{@}$ uonbi.ac.ke)

M. Munjuri

Human Resource Department, University of Nairobi, Kenya.

(mercy.gacheri@uonbi.ac.ke)

J. Kagwe

Project Management Department,

University of Nairobi, Kenya.

(jkagwe@uonbi.ac.ke)

*Corresponding Author especially in the emerging markets where competition is low and chances of increasing their market share is high. The desire to internationalise is seen as normal and reasonable in the sense that emerging markets are increasingly growing in terms of their population which indicates that a multinational firm has a higher chance of gaining financially with the introduction of their products and services in new markets. In essence, their product consumption is more assured [23]. 
Multinational firms are constantly competing to be at the top tier of the pyramid while at the same time dealing with the global business environmental changes that are shaped by globalization of economies. The authors defined a multinational firm as an entity that has operations in more than one country [24]. A multinational firm is a business entity that has operations in more than two countries, in essence, the home country and the host country [25].

These entities often oversee business activities such as manufacturing and production of goods and services in other countries. The author notes that multinational firms have influenced globalization with their international expansion activities. Further, the author maintains that because of globalization and removal of trade barriers, the world is now a small global village.

Companies that are listed or officially registered in different foreign countries as either private or public companies are considered to be multinational. The author states that the functions of one subsidiary can have a significant effect on the functions of other subsidiaries depending on the variation in the degree of autonomy in the entire corporation. From the above definitions and descriptions of multinational firms, it is clear that not only do these firms operate subsidiaries in different countries, but also through them, goods and services are produced and sold to increase their global footprint [10].

Multinational firms use performance behaviours of subsidiaries to form new entry strategies into foreign markets. The main aim of evaluating how firms perform abroad is to help investment managers operationalize the effective use of resources in the host country and possibly in a new market. Multinational firms measure their performance through regional subsidiaries by allowing the regional branches to establish the local ways of measuring performance. Managers in different regions will assess performance using different models [43].

Comparable arguments by [30] that highlighted those of [43] indicates that a multinational firm will first think about the financial benefits of entering a foreign market and the impact on its performance before it decides to internationalize. This means that its sales revenue will depend on the external factors existing in the new market. Further, the firm will need to consider the amount of resources needed in its expansion activities and compare the cost of going global versus choosing to operate in its home country.

When all the necessary factors are considered, the firm should only engage in international projects that are economical yet profitable and more attractive than the home country projects.

Other authors who researched on the internationalization of business included [27] who establishes that a multinational firm setting up operations in a host country needs to consider the cost of transferring human expertise and experienced employees from home country to the new country of interest. Hence for successful performance and longevity of operation, a firm should accustom itself to the new host environment by acquiring new strengths that will enable it compete on the same level field as its peers so as to benefit more as it expands abroad.

Business competition in foreign markets is often informed by the demand or the need for firms to invest abroad which influences the type of strategy to use in entering the market. The form of entry will be identified if the firm's operational activities are to be conducted entirely or partially in the home or host country. The strategy chosen will also specify the need for investment [37].

Foreign market entry strategies have been defined by [28] as the strategic decisions and choices that a firm considers when it intends to enter an international market. The manner in which a firm decides to extend its operations in a foreign country largely depends on the policies and procedures put in place on its internationalization processes. Globalization has enabled firms to introduce new products, unique resources, human skills and managerial techniques into foreign markets. As a result, the strategy they choose to penetrate new markets is of paramount importance and has a significant effect on the overall performance of the firms.

Additionally, multinational firms that are keen on global expansion can choose two known modes to enter foreign markets, the equity mode, and the non-equity mode [16]. Equity modes of entry are considered to be of uppermost risk but with maximum market control and good return on investment. They are associated with joint ventures, acquisition and wholly owned subsidiaries. [41] explains that non-equity modes have been considered to have the least market control since firms who choose any of the entry modes in this category risk facing market entrance threats and rejection. They include exporting, licensing, franchising, contractual business [26].

An attempt to emphasise on the need for more entry strategies studies has been voiced by [18] who in their paper defined acquisition as the manner in which a firm uses ownership to obtain controlling power of another firm in another country. He points out that acquisition forms can differ from one firm to another depending on the objectives and goals of a given firm. They can be categorised as partial acquisition or full acquisition. [43] argues that a partial acquisition is where a foreign firm acquires only a portion of the equity of the local firm giving it a degree of control of the local firm. However, full acquisition allows the parent firm to obtain total control of the operations of the foreign firm since the takeover involves the entire stake of the firm.

This type of entry strategy has been viewed as an expensive method especially when the host country has a weak currency. [55] further adds that acquisition is mostly considered a costly affair when the parent firm desires a full acquisition of the local firm in order to become a local firm so to gain full access to the local market and to have the ability of controlling its market share. The authors argue that the benefit of fully acquiring a foreign firm can only be determined through its performance in the local market for the acquisition process not only involves purchasing of customers but all other stakeholders associated with the firm's products. In essence, the competitors, suppliers and distributors.

Exporting business has been described as the activities that involve a manufacturing firm in one country selling its end products to another country [1]. This mode of entry is found to be of low risk by exporting firms since it's a cost-effective method. Through this method, a firm is able to efficiently sell its high-quality standard and unique products in foreign countries for purposes of growing the products and increasing 
its shelf life. [5] points out that multinational firms using exporting to gain entry into foreign markets are often keen in exploring the local markets to gain knowledge of competitiveness from their peer firms. A firm is also driven to use this method if the competition at home is stiff.

A book written on international market selection strategies by [50] discusses wholly owned subsidiaries as the method of entry in which a foreign firm identifies a local country of interest and sets up business operations by building new establishments or purchasing a pre-existing one. This mode of entry is considered to be of a higher risk but it comes with a high control of the local market. The mode is also considered to involve a lot of investments in resources, time and money when setting up. Simply put, multinational firms would rather use wholly owned subsidiary or Greenfield as an entry method when penetrating new markets since the financial rewards far outweighs the cost of establishment [37].

Franchising is a mode of entry where a multinational firm in a foreign country sells its business concepts to an identified firm in the host country as a business expansion strategy. The franchisor will sell its branded products and services to the franchisee while maintaining control of how the products are marketed and distributed in the host country and in exchange, the franchisee pays a certain amount of fees and agrees to run the business according the franchisors terms [14]. Franchising is considered the better mode of entry strategy compared to the other strategies since it is a low risk mode and there is absolute independence when it comes to operational activities between the two parties in the agreement.

Performance is the measure put in place to show what and how an individual or a group has accomplished over a period of time [3]. Mejlumyan [28] on the other hand defines performance as the amount of information collected to illustrate a company's growth. Performance of firms is linked to management tools that steer it into achieving its set goals and objectives. A firm is considered to be successful if the set goals are achieved and the amount of resources used to accomplish its goals.

Performance of multinational firms is often evaluated using either financial or non-financial indicators to help establish the sources of profits. How a subsidiary is performing abroad is of crucial importance to the parent company. [41] argues that financial performance of multinational firms is a construct that is intricate and multifaceted. For example, some firms purchase equity of firms in foreign markets to increase their market share which in turn may indicate a strong financial performance. On the other hand, a firm entering a new market for the first time may experience a sharp increase in its costs as it advertises its new products in the new market and tries to create its brand awareness.

Other studies done have given a clear indication that the choice of entry into a foreign market significantly influences the financial performance of multinational firms given the high market risks, cost of establishments and strength of foreign currencies associated with the host countries [20]. For it to achieve its objectives, the study will focus on only the financial indicators of performance of multinational firms.
This will include Sales growth, Return on Assets, Return on Equity and Return in Capital Employed.

\section{RESEARCH PROBLEM}

Due to globalization, the environment in which firms operate has become dynamic, multifaceted and ever changing. Performance of a multinational firm in a foreign market is greatly influenced by the mode of entry used. [1] did a study on the process of selecting an entry mode into foreign markets. The author found that choosing the right entry mode was a challenging task to managers of international business in terms choosing the right resources, the right time to expand and the amount of money to use in their expansion strategies.

A study done by [28] found that the type of strategy a firm decides to use has a direct impact on its financial performance. For example, choosing a low risk strategy does not guarantee greater investment returns. While at the same time, a high-risk strategy that is mostly associated with high investment returns such as a wholly owned subsidiary may result in losses if the expansion plan is not carefully crafted out. The author concluded that there was no appropriate strategy to use to internationalize, neither was there one to avoid. [37] study on new market entry strategies established that foreign firms preferred using wholly owned subsidiaries over all other forms of entry. The author stressed that using of a specific entry strategy entirely depended on the company's goals and objectives. However, using a strategy that was in line with the firm's mission and objectives was paramount.

Another study done by [3] on the difference in the type of entry strategies used in developed and emerging markets revealed that firms adopted an entry strategy that was driven by the need for closeness to customers and the size of international operations. The author further revealed that the regulation of content, host country bureaucracy and the uncertainty of politics affected the mode of entry choice. Other challenges found by [55] that multinational firms faced while penetrating foreign markets included political risks, legal issues and choosing the wrong strategy that eventually gave them a competitive disadvantage. [26] book on across borders and cultures management revealed that corporate interest in foreign markets had over the years barred firms from setting up establishments in new markets. Further, firms found it difficult to invest in countries whose currencies were weak leading up to difficulties in setting up their businesses as the costs of currency conversion outweighed the profits.

Low population of the host country has also played a role in the performance of multinational firms as with a low population, consumption of goods is likely to be low regardless of the product's popularity in the home country. A less populous economy interprets to reduced buyers with less confidence in the foreign firm's products. Multinational firms that often risk investing in such economies are likely to suffer a financial blow with such consumer behaviour. Multinational firms that chose franchising as a mode of entry sometimes experienced lack of protection of their trademarks and copyrights. Where the government of the host country failed to offer such protection, the multinational firm risked other players in the market copying their business ideas [41] 
An article written to emphasise on the need for more research to be carried out on foreign entry strategies by [18] found that the process of entering a foreign market was structured around replicating the previous strategies used. The authors concluded that the questions often asked on future entry modes research should focus on the repercussions of investing in a less advanced economy in terms of technology, skilled labour, advanced communication and transportation systems. These factors if not carefully considered may affect the performance of multinationals and the period in which it takes to benefit from their investments abroad may be longer.

A possible shortcoming on the above studies is that the potential impact of foreign market entry strategies on the financial performance of multinational firms have not been explored in depth. More so, the above studies were focused on developed markets that have a well-established financial structure. This study will emphasis on Kenya as an emerging market with the potential of giving multinational firms access to other bigger developing markets. The studies are deemed incomplete in their coverage and the current study will attempt to fill this gap. In addition, the study chooses to focus on the multinationals operating in Kenya and examine the different strategies that are used by the ones currently listed at the Nairobi Securities Exchange. In particular, it seeks to find out the financial challenges associated by the different strategies the firms chose.

\section{LITERATURE REVIEW}

To determine the objective of this study, applicable literature will be reviewed in association with the study variables. Significant theory to the study will be discussed including the researchers view and review on the theory.

\section{THEORETICAL FOUNDATION}

This study was supported by Transaction Cost Theory and the Internationalization Theory as the anchoring theory. Transaction Cost is the cost that firms incur in marketing their goods and services. The author stressed that it was impossible to practically comprehend how the economic system of a host market worked without considering the transaction costs. Coarse notes that when proposals of transactional cost framework are well adhered to by firms, they perform better. Firms with a higher transaction cost are likely to obtain higher levels of control in foreign markets [17].

Transaction cost theory has been criticised by stating that the theory only focused on minimizing the cost of internationalization while downplaying the actual expenses incurred on overseas operations. The authors established that the theory was not practical as it contained a number of confinements. It lacked a wholesome approach in its framework for it was devoid of the cost of minimization and the economic transactions incurred from the social relationships formed [33].

Internationalization theory encourages multinational firms to take up the opportunities in foreign countries that allow for establishment of subsidiaries so to capitalize on the competitive advantages. Since its origin, the theory has gone through numerous transitions due to advanced technology and different trade policies. Research done on Internationalization theory has attempted to provide a deep understanding on the impact of the theory on today's multinational firms. Before going global, multinational firms should explore the resources it has internally first especially knowledge-based resources and its assets [9].

The authors further state that having this kind of knowledge is particularly important when the laws and rights around intellectual property is weak in the country of interest. Moreover, attention is usually given on the disadvantages that foreign markets have when it comes to international knowledge transfer and none at all on the costs that a firm would incur while transferring the same knowledge. The theory only brought into light the values a firm would obtain from technology transfer. He states that the theory disregards the basic information on acquisition and other modes of entry pose managerial difficulties and the costs of these difficulties cannot be simply tabulated [11].

Irrespective of the failures brought about by the theory, it is considered significant to the study since it looks for and validates the choices a firm should make when internationalizing. The theory also has significant contributions towards international business management, an important value that this study will add to new knowledge. The interaction between the international business world and the ever-changing business environment where multinational firms can pursue the internationalization theory as a strategy is a relevant feature in making this theory powerful to utilize in this study.

\section{EMPIRICAL FRAMEWORK}

Studies on entry into foreign markets had gained a lot of popularity in the recent years to an extent it had been established that there isn't a right or wrong strategy of entering a new market [42]. The topic of foreign market entry is an important one for it looks at the strategic decisions of multinational firms wishing to enter foreign markets [5], [7]. In particular, these strategies play a critical role on financial performance of multinational firms. While previous studies have shown that each strategy used by a multinational is associated with risk, cost, control, and return [45], [46] and [54] observed that the link between the mode of entry and the financial benefits of operating abroad were generally neglected.

Before going into a foreign market, [24] suggested that firm needed to set its objectives and policies right, have an estimated volume of profits from foreign sales, decide on the number of target countries, and take caution not to expand outside their financial capabilities. The authors emphasized that a country's business environment influenced firms in deciding on the best entry mode to use for optimum returns. [42] further detailed that multinational firms should critically analyse the country of interest and ensure that it was business friendly and has a ready market for their products.

However, [42] cautioned firms to be aware of investing into countries that face challenges such as low population or poor advanced economy which would put a strain on performance. Other factors such as trade barriers and a dynamic economic environment should be of paramount 
when making foreign entry decisions. According to [2] acquisition under the equity mode of entry was a widely preferred form of venturing into international markets because it posed lower risks. This kind of entry mode enabled a firm to acquire total control of another firm in the host country through purchase of its stock.

Acquisitions were most preferred since a multinational firm was able to establish itself in the host country as quickly and with minimum risk in the new foreign market. This type of entry into a foreign market was often viewed as an expensive affair especially when acquiring a firm that was established in a country with a weak currency and high interest rates. In addition, property rights, laws and regulations governing the firm in the host country was something of a concern to international business managers. [37] Mirrored this argument and stated that developed countries such as China tended to have strict laws and restrictions on foreign firms owning businesses in their country as opposed to developing countries such as the Philippine that possessed more leniency to foreign business ownership.

Statements quantifying acquisition as an entry strategy by [55] was said to be the best when the firm was more focused on scaling its business only if there was need to scale-up the business to another level. This entry strategy was also considered the best when the firm was more interested in consolidating its business operations into one entity. [44] on the other hand argued that acquisitions were a risky affair for it could possibly fail to increase the market share of the firms' products or fail to increase the market value of the acquired firm.

Research findings by [40] purported that with acquisition strategy, it was easy for a firm to estimate its financial returns precisely since the parent firm not only acquired the local firm whether fully or partially, but it also acquired its competitors, distributors, and local suppliers. He however cautioned that acquisition of any kind was only considered attractive when the local firm was well established and operating in the region of business interest of the parent firm.

Exporting on the other hand was examined by [6] and considered a more preferred mode of entry due to the low risk level around it especially the cost of creation. [12] Revealed that multinational firms that used exporting as an entry strategy were more successful financially than those who used other strategies. This was because running an exporting business gave these firms the opportunity to access varieties of markets and where the host country's population was large, they were able to advertise and sell more of their products with the potential result of increasing the lifespan of their products.

Other observations revealed that multinational firms were more guaranteed to growing internationally or exploring the prospects of selling overseas if they exported their products gradually. They established that internationalization was a more unidirectional procedure that required firms to persistently acquire adequate knowledge and experience of operating in foreign markets [22].

Contradicting statements by [13] suggested that for a multinational firm to reap profits from exporting strategy, there needed to be a strong partnership between the host country government, the foreign customer, the importing firm, the exporting firm and the transportation means that the products would be channeled through. They emphasised that if this relationship was not well coordinated, the exporting firm risked incurring financial losses. The benefits of using a joint venture as a form of entry was considered to outweigh the challenges since in such a partnership; everything was shared half-half [1].

Exporting mode was considered advantageous as the partnering firms were able to create a joint financial strength and share the risks and liabilities of operating abroad. Although some multinational firms found this means as the better strategy of entering into a new country, other firms feared the risk of partner firms wanting to terminate a contract in order to venture in a different direction from that of the initial contract [4].

Multinational firms using this strategy as to gain entry were likely to face challenges such as control and ownership, conflicting goals and objectives of the partners, and obtain their investment capital back when they wished to terminate and exit the partnership [36]. In such unforeseen situations, a foreign firm getting into a partial joint-venture needs to carefully examine and map its goals, objectives and expectations and ensure that they are aligned with those of the partnering firm in order to avoid such complications.

Multinationals that chose a wholly owned subsidiary or the establishment of a wholly owned subsidiary as a mode of entry often wanted to control the foreign markets for it came with a higher degree of market control [50]. [44] agreed by pointing out that wholly owned subsidiary took a great investment of time and resources to set up operations, marketing engagement was more and establishing a distribution network was paramount to be able to compete with existing businesses.

According to [37] multinationals preferred setting up a wholly owned subsidiary in other nations as their only route to internationalizing especially when they needed to have full oversight over operational exercises. Wholly owned subsidiary operations came with benefits and challenges. The benefits of this mode included the high level of controls that multinationals have over the local firms. Firms were also able to control the quality of products supplied to the market while controlling their image and brand name [46].

At the same time, this type of entry mode saw multinational firms face challenges such as excessive control of government regulations that deterred investments and high market entry costs. A parent firm purchasing $100 \%$ of its stake to become a wholly owned subsidiary required the firm to this acquisition as the parent firm was expected to undertake the responsibilities of operating in a new market that possessed different political views, culture, economy and currencies that were different from its home country. The assumption of new responsibilities of running a foreign business in a new market as a newly wholly owned subsidiary posed challenges and cost complications. However, he pointed out that the financial benefits of this mode were optimum and worth exploring [22].

A study done on franchising by [18] on international business established that multinational firms viewed this strategy as a cost effective one since it helped the firms to obtain the ability to centrally control its business operations in foreign firms with less capital investment. Studies done on 
this topic have revealed that the franchisor is solely responsible for controlling the profits made by the franchisee, surviving in the foreign market and the advertising strategies to be used in order to maintain a competitive advantage in its franchise network.

Other researchers such as [5] have established that using a franchise as a method of entry into a new market was most preferred among multinational firms who were risk averse and not willing to spend all of its resources in creating an entity. Rather, their goal was to establish new international markets as quickly as possible. He argued that the idea to enter new markets using franchises was to maximize on global profits and minimize on entry costs. [11] Suggested that multinational firms should not extend their franchising businesses to countries that experienced weak laws in order to protect their advancements in technology and quality service offers to their competitors.

Operating a franchise in different countries was significant to the financial performance of the franchisor as it enabled it to benefit from the resources of the franchisee. The foreign customer was also considered to benefit from the activities of both the franchisor and franchisee since he or she would have access to quality products at reasonable prices [19].

\section{PERFORMANCE OF MULTINATIONAL FIRMS}

Literature reviewed indicated that the main issue that a multinational firm was concerned with was whether the investments in the target market would yield any profits and if operations of its business activities were solely sustainable. Firms use both financial and non-financial indicators to monitor performance of its subsidiaries. This article will focus on financial indicators such as return on equity, return on assets, sales growth and return on capital employed to measure performance of multinational firms [48].

Moreover, financial performance of global firms was an intricate and multifaceted construct. For instance, an expansion in share market may express that the firm has purchased equity by cutting off costs, or putting intensely in advancements. Nonetheless, the metric itself doesn't tell whether a company's primary profit has really improved. Moreover, when a firm is entering a new market, it might experience momentary budgetary misfortunes as it increases experiential information or creates brand awareness, which may later be significant drivers of performance [41].

Attempted arguments by [2] contended that firms that decide to invest their businesses abroad were influenced by several factors such as global expansion, a bigger market share, and a global name, acquisition of new resources, large profits and stiff competition in the home market. For a company to successfully transition its operations into a new foreign market, time and resources were to be consumed. The appropriate strategy of penetrating new markets was a significant effect on the overall performance of multinationals operating abroad. Therefore, the mode of entry ought to be chosen carefully and much thought put in place.

A paper written to emphasis on the reasons of going abroad by [18] posited that using a wrong strategy would result in poor performance as the firm would spend more time struggling to learn about the new market's policies, competitiveness as opposed to selecting the right strategy to use. The authors further argued that a multinational firm that wants to invest abroad will take time to select the best foreign markets where it thinks its international objectives will best be achieved. Depending on the firm's level of resources, it will then select the right strategy to enter the market. In their findings, they suggested that an entry strategy to be driven by the foreign market's demand of the firm's products and services, other firms in the new market selling similar products, and the host country's overall market performance.

\section{SuMmary OF EMPIRICAL REVIEW AND KNOWLEDGE GAP}

The country of interest is crucial in deciding whether and how to go global in that if the products the firm is interested in introducing in the new market are on demand and the country's performance is poorly ranked, then the firm will need to re-think or reconsider investing in that country. These considerations should be reviewed and re-evaluated for shortand long-term investment goals.

The journal article by [18] emphasised on the reasons why firms require more foreign entry strategies. [42] reviewed the United States of America and China business relations in relation to the entry strategies used by firms in either county. [5] Wrote on the choices of foreign entry strategies that service firms used in their internationalization process. [2] Examined the financial performance of manufacturing firms in Kenya and the entry strategies they used to enter the country. [37] Did an empirical review on foreign market entry strategies while [52] studied the factors that influenced the choice of entry into foreign markets.

A study focused on the overall performance of manufacturing firms in Kenya by [44] concentrated on the entry strategies firms used and their characteristics. [47] Explored optimism, religion and the non-equity entry modes that international firms utilised to gain entry into foreign markets. [41] did an empirical analysis on the concepts of uncertainty and their impact on the choice of entry strategies into foreign markets and found that the level of uncertainty in a host country significantly affected the performance of multinational firms.

A significant shortcoming of the above studies is that, with the exception of a handful of studies that have explored foreign market entry strategic decisions into Asia, Scandinavian countries and Europe, these studies have entirely focused on foreign entry strategies into new markets but were incomplete in their coverage for the studies did not elaborate on the financial performance of multinational firms, more so the ones operating in Kenya and listed at the Nairobi Securities Exchange. This article will try and fill this gap by answering the question, what are the effects of foreign market entry strategies on the financial performance of listed multinational firms in Kenya?

\section{RESEARCH METHODOLOGY}

A cross-sectional research design was utilized in this study. The design was deemed fit as it examined the relationship between the study variables over a short period of time. In essence, for the financial periods of 2017, 2016, 2015 and 
2014 which informed the source of financial data. Data on the independent variable of the study was directly obtained from the firms' websites. The research design chosen implemented both descriptive and analytical study types. The population of the study was confined in one country hence the preference of a descriptive study. To help arrive at concrete conclusions on the relationship between the variables, an analytical study type was also adopted.

A list of multinational firms listed in the Nairobi Securities Exchange in Kenya ( $n=62$ ) was obtained from the company's website. The study relied on secondary data which was obtained from the latest annual reports of the respective multinational firms. The sources of data included; audited financial statements for the years mentioned above. Data collected was analyzed using quantitative methods. Descriptive statistics was used in the preliminary analysis. Simple linear regression analysis was used to test for the relationship between the independent and the dependent variable. Findings were presented using tables, graphs and charts. The variables of the study, foreign market entry strategies and financial performance of multinational firms were measured as; Return on Assets, Return on Equity, Sales Growth and Return on Capital Employed to measure financial firm performance. On the other hand, foreign market entry strategies were measured using Exporting, Franchising, Acquisitions and Wholly Owned Subsidiaries.

\section{RESUlTS AND DisCUSSION}

To determine the relationship between entry strategies into foreign markets and financial performance of multinational firms that participated in this study, a simple linear regression was done using Stata software. The entry strategies namely exporting, franchising, wholly owned subsidiaries, and acquisitions were regressed against performance measures of the firm's sales growth, return on equity, return on capital employed and return on assets. The entry strategies were the independent variables while the performance measures were the dependent variables.

The number of firms that participated in the study were those registered at the Nairobi Securities Exchange Handbook (2019). To have a proper forecast of performance of multinational firms operating in Kenya, their financial performance trend between 2014 and 2017 was used to measure the firms' profitability and efficiency in the use of capital and net assets. Each of the firm's sale growth, return on equity, return on capital employed and return on assets was used to measure performance.

TABLE I: FOREIGN MARKET ENTRY STRATEGIES Foreign market entry strategies

\begin{tabular}{cc} 
Foreign market entry strategies & \\
\hline Exporting & 3.23 \\
Franchise outlets & 11.29 \\
Wholly owned subsidiary & 82.26 \\
Acquisition & 3.23 \\
\hline
\end{tabular}

Source: Research Data 2019.

On average, majority of these multinational firms (82\%) entered the market as wholly owned subsidiaries or as foreign direct investors. The results of the regression model are shown above.

A hypothesis was formulated out of the objectives of this study which read as;

H1: There is a significant relationship between foreign market entry strategies and financial performance of multinational firms.

TABLE II: Foreign MARKET ENTRY STRATEGY AND FINANCIAL PERFORMANCE

\begin{tabular}{|c|c|c|c|c|c|c|c|c|}
\hline & \multicolumn{4}{|c|}{ Unadjusted model } & \multicolumn{4}{|c|}{ Adjusted model } \\
\hline & Coef. & $\mathrm{P}>\mathrm{t}$ & \multicolumn{2}{|c|}{$\begin{array}{c}\text { [95\% Conf. } \\
\text { Interval] }\end{array}$} & Coef. & $\mathrm{P}>\mathrm{t}$ & \multicolumn{2}{|c|}{$\begin{array}{c}\text { [95\% Conf. } \\
\text { Interval] }\end{array}$} \\
\hline Exporting (ref) & -0.53 & 0.00 & -0.83 & -0.24 & -0.53 & 0.00 & -0.82 & -0.23 \\
\hline Franchise outlets & -0.57 & 0.00 & -0.83 & -0.31 & -0.57 & 0.00 & -0.83 & -0.31 \\
\hline Wholly owned subsidiary & -0.59 & 0.00 & -0.95 & -0.22 & -0.60 & 0.00 & -0.97 & -0.23 \\
\hline $\begin{array}{l}\text { Acquisition } \\
\text { ROE }\end{array}$ & \multicolumn{7}{|c|}{ ROE } & 0.85 \\
\hline Exporting (ref) & -0.66 & 0.00 & -1.09 & -0.22 & -0.65 & 0.00 & -1.02 & -0.27 \\
\hline Franchise outlets & -0.67 & 0.00 & -1.06 & -0.27 & -0.65 & 0.00 & -0.98 & -0.31 \\
\hline Wholly owned subsidiary & -0.80 & 0.01 & -1.35 & -0.26 & -0.84 & 0.00 & -1.31 & -0.37 \\
\hline \multicolumn{9}{|l|}{ ROA } \\
\hline Exporting (ref) & -0.09 & 0.36 & -0.29 & 0.11 & -0.11 & 0.26 & -0.31 & 0.08 \\
\hline Franchise outlets & -0.13 & 0.14 & -0.31 & 0.04 & -0.14 & 0.11 & -0.31 & 0.03 \\
\hline Wholly owned subsidiary & -0.20 & 0.11 & -0.44 & 0.05 & -0.23 & 0.06 & -0.48 & 0.01 \\
\hline $\begin{array}{l}\text { Acquisition } \\
\text { ROCE }\end{array}$ & 0.17 & 0.05 & 0.00 & 0.35 & 0.15 & 0.09 & -0.03 & 0.32 \\
\hline Exporting (ref) & -0.70 & 0.20 & -1.80 & 0.39 & -0.65 & 0.25 & -1.79 & 0.48 \\
\hline Franchise outlets & -0.62 & 0.21 & -1.61 & 0.36 & -0.59 & 0.24 & -1.60 & 0.42 \\
\hline Wholly owned subsidiary & -0.95 & 0.17 & -2.32 & 0.41 & -0.91 & 0.21 & -2.32 & 0.51 \\
\hline Acquisition & 0.92 & 0.06 & -0.05 & 1.88 & 0.94 & 0.07 & -0.07 & 1.96 \\
\hline \multicolumn{9}{|l|}{ Overall performance index } \\
\hline Exporting (ref) & -2.09 & 0.04 & -4.12 & -0.06 & -2.02 & 0.05 & -4.03 & -0.01 \\
\hline Franchise outlets & -2.01 & 0.03 & -3.84 & -0.19 & -1.94 & 0.03 & -3.73 & -0.15 \\
\hline Wholly owned subsidiary & -2.68 & 0.04 & -5.21 & -0.15 & -2.72 & 0.03 & -5.23 & -0.21 \\
\hline \multirow[t]{2}{*}{ Acquisition } & 1.98 & 0.03 & 0.19 & 3.77 & 1.87 & 0.04 & 0.08 & 3.66 \\
\hline & & for $\mathrm{Sa}$ & owth, R & Equity & on Ass & eturn & l Emplc & \\
\hline
\end{tabular}

Source: Research Data 2019. 
To test the above hypothesis, a simple linear regression was used. As indicated in both the adjusted and unadjusted regression models, the correlation coefficient for the association between Franchising mode of entry and sales growth of financial performance was $\mathrm{R}=0.57$. The $\mathrm{P}$ value $=0.00$. Those of Wholly owned subsidiaries, Exporting and Acquisition was $\mathrm{R}=059, \mathrm{R}=0.53$ and $\mathrm{R}=0.62$ respectively. The $\mathrm{P}-$ values equaled 0.00 .

The correlation coefficient between Return on Equity and Franchise mode of entry was $\mathrm{R}=0.67$. The $\mathrm{P}$ values $=0.00$. Export entry modes, wholly owned subsidiaries and acquisitions reported a correlation of $\mathrm{R}=0.66, \mathrm{R}=0.80$, and $\mathrm{R}=0.78$. The $\mathrm{P}$ values were 0.00 except for wholly owned subsidiaries which reported a $\mathrm{P}$ value of 0.01 .

As for Return on Assets, the relationship between Franchising and return on assets resulted in $\mathrm{R}=0.13$ with a $\mathrm{P}=$ value of 0.14 . Exporting, Wholly Owned Subsidiary and Acquisitions all gave a coefficient of $R=0.09, R=0.20$ and $\mathrm{R}=0.17$. All of their $\mathrm{P}$ values were greater than 0.05 , i.e. $\mathrm{P}>0.05$ except for acquisitions which reported a $\mathrm{P}$ value equal to 0.05 .

The relationship between Return on Capital Employed and Foreign Market Entry Strategies was also tested. Franchise outlets resulted in a coefficient of $\mathrm{R}=0.62$ while exports, wholly owned subsidiaries and acquisitions resulted in $\mathrm{R}=0.70, \mathrm{R}=0.95$ and $\mathrm{R}=0.92$. The $\mathrm{P}$ values for Exports, Franchise, Wholly Owned Subsidiaries and Acquisitions were as $\mathrm{P}=0.02, \mathrm{P}=0.21, \mathrm{P}=0.17$ and $\mathrm{P}=0.06$. The table below details the coefficient correlations of performance and foreign market entry strategies.

Findings reveals that the performance of multinationals that used franchising, acquisitions and wholly owned subsidiary as an entry strategy had a significantly lower performance compared to the performance of multinationals that used exporting. This finding is consistent with the findings of other authors such as [52] and [50]. These findings also corroborates previous evidence from other studies on effect of foreign market entry strategies on financial performance [11], [29], [38] and [53] .

The paper on modelling the speed of entering international markets by [38] found that multinational firms that operated in foreign countries as exports were more successful financially than those who chose other modes of entry mentioned in this study. Similarly, [50] found that exporting firms had a significant level of financial growth from their international sales. Therefore, the findings of this study have given an implication on the positive relationship between exporting strategy and firm financial performance. A possible explanation to this finding could be that exporting firms incur much less investment costs of establishment into the foreign markets and they also face low market threats.

Another explanation for the success of exporting firms is that for the goods and services exported to foreign markets, they are not mandated to be produced in the host country but rather the home country. With this exemption, the cost of investment in host countries becomes lower as opposed to the cost of establishing a wholly owned subsidiary or an acquisition [33].

Other studies have shown that firms using exporting as an entry strategy experience the advantages of rapid global market entry. In addition, exporting proves to be an easy to manage point of entry as the managers are able to quickly identify their competitors, distributors and sales agents that they can work with [47].

\section{CONCLUSION}

The study was based on the publicly listed multinational firms operating in Kenya. The anchoring theory for this study was the Internationalization Theory. The hypothesis tested was supported to be of statistical significance. From the results obtained, it was observed that exporting firms were more successful in their financial performance compared to firms that penetrated the Kenyan market as Wholly Owned Subsidiaries, Franchise or Acquisitions.

From the results, it has been established that a significant relationship between foreign market entry strategies influences the financial performance of multinational firms. Conclusively, the study findings imply that multinational firms should conduct a market research in the country of interest prior to making investment decisions $s$ to properly choose the right entry strategy for an improved financial performance. The study also concludes that choosing the right entry strategy will not guarantee great financial returns and that other factors such the strength of currency, population, economy and other environmental factors contribute in entry mode decision making.

\section{RECOMMENDATION}

It is recommended that management of multinational firms should continue expanding their international operations in other countries if the expansion reasons are aligned with their goals and objectives. In addition, the firm should come up with an entry strategy that is core to long term performance in the international markets for continuity of business.

\section{LIMITATIONS OF THE STUDY}

The study encountered certain limitations during its course. However, these limitations did not interfere with the results nor the quality of the study. The initial limitation was that the information utilized in this study depended on the firms' yearly financial reports of 2014, 2015, 2016 and 2017. Future inquiries that utilizes other forms of information might be encouraged to use more recent data to come up with a more sophisticated conclusion. A cross-sectional research approach was another limitation. Given that global business activities are a constant and dynamic procedure, a longitudinal research design spreading over several years can without a doubt further advance the comprehension of the dynamic causal connections between the two variables studied.

Another limitation was to what extent the study's findings could be generalized to fit other countries given the small sample size of the population. In addition, the study only focused on the 62 publicly listed multinational firms in Kenya. This is so because the data needed to answer the objective of the study was readily available in the firms' websites. And since the study was limited to the financial aspects of performance, it only utilised secondary data. 
Despite these limitations, the findings however provided useful insights on how to form an entry strategy framework engrossed on circumstances in the foreign market.

\section{SUGGestions FOR Future RESEARCH}

This study only involved publicly listed multinational firms in Kenya. Future studies could carry out a similar study on all the multinational firms in Kenya, whether listed or not. Future research can also introduce other variables that are likely to affect the performance multinational firms in foreign countries such laws and regulations governing the ownership of business in foreign countries, currency performance, internal factors of the firm and other macro-economic factors not mentioned in the study. A longitudinal research spanning over a longer period of time may also be considered to give a comprehensive result on the relationship between the two variables studied. It is also suggested that other forms of entry strategies such as joint-ventures, contract manufacturing, licensing and Turnkey Projects could be studied alongside the ones studied in the current study.

\section{REFERENCES}

[1] G. Annica, "The selection of entry mode when penetrating a foreign market'. Unpublished Master's Thesis of Linnaeus University (2011).

[2] R. Arasa and L. G. Nduku. "The influence of International Market entry strategies on firm financial performance: A study of the Manufacturing Multinationals in Kenya", International Journal of Economics, Commerce and Management, 3(9) 364-386, 2015.

[3] H. Arnstorp, "Foreign market entry strategies in developed and emerging economies. A case study of entry strategies of Norwegian oil service firms", Unpublished master's thesis of the Norwegian University of Science and Technology, 2013.

[4] P. S. Aulakh, M. Rotate, and H. Teegen, "Export strategies and performance of firms from emerging economies: Evidence from Brazil, Chile, and Mexico". Academy of Management Journal, 43(3), 342$361,2000$.

[5] A. Blomstermo, D. Deo Sharma, and J. Sallis. "Choice of foreign market entry mode in service firms. International Marketing Review, 23(2), 211-229, 2006.

[6] M. Brookes and A. Roper. "The impact of entry modes on the organizational design of international hotel chains". The Service Industries Journal Vol. 30, No. 9, pp 1499-1512, 2010.

[7] K. D. Brouthers and J F. Hennart. "Boundaries of the firm: Insights from international entry mode research". Journal of management, 33(3), 395-425, 2007.

[8] L. E. Brouthers, G. Nakos, J. Hadjimarcou and K.D. Brouthers. "Key Factors for Successful Export Performance for Small Firms". Journal of International Marketing, 17(3), 21-38, 2009.

[9] P. J. Buckley, and R. Stranger. "The governance of the multinational enterprise: insights from internalization theory". Journal of Management Studies, 48(2), 460-470, 2011.

[10] R. E. Caves. "Multinational enterprises and technology transfer, in Rugman, A.M. (ed.) New Theories of the Multinational Enterprise, St Martin's Press, New York', pp. 254-79, 2013.

[11] S. J. Chang and P.M. Rosenzweig. "The choice of entry mode in sequential foreign direct investment'. Strategic management journal, 22(8), 747-776, 2001.

[12] H. Chung and P. Enderwick. "Investigation of Market Entry Strategy Selection: Exporting vs. Foreign Direct Investment Modes-A Homehost Country Scenario", Journal of Management, VOL 18, pp 443460, 2001.

[13] F. J. Contractor, S. K. Kundu and C-C. Hsu. "A three-stage theory of international expansion: the link between multinationality and performance in the service sector", Journal of International Business Studies, Vol. 34 No. 1, pp. 5-18, 2003.

[14] M. K. Erramilli. "Entry Mode Choice in Service Industries" International Marketing Review, Vol. 7 No. 5 pp 50-62. 1990.

[15] M. K. Erramilli and C. Rao. "Service Firms' International Entry-Mode Choice: A Modified Transaction-Cost Analysis", the Journal of Marketing, Vol 57, No 3 pp 19-38, 1993.
[16] H. Deresky. “International Management: Managing Across Borders and Cultures, Text and Cases". Boston: Pearson Education. 2011.

[17] P. Doyle. "International Management: Managing Across Borders and Cultures, Text and Cases". Boston: Pearson Education. 2011.

[18] J. Hennart, and A. H. L. Slangen, "Yes, we really do need more entry strategies studies! Commentary on Shaver", Journal of International Business Studies, 46(1), 114-122, 2015.

[19] S. Hollensen. Global Marketing: "A Decision-Oriented Approach". Pearson Education, Upper Saddle River. 2007.

[20] Hongren, Harrison, and Oliver. "Financial management accounting", (2nd edition.). Pearson Prentice Hall. 2009.

[21] J. Ishimwe. "Foreign Market Entry Strategies Adopted by Tigo to Enter into Rwandan Telecom Market". Interdisciplinary Journal of Contemporary Research in Business, 2(2), 89-91, 2013.

[22] J. Johanson and J.-E. Vahlne. "The internationalization process of the firm - a model of knowledge development and increasing foreign market commitments". Journal of International Business Studies, 8(1), 23-32, 1977.

[23] P. Kobe. "Foreign Market Entry Strategies Adopted by Kenya Commercial Bank Limited in Rwanda". International Journal of Research in Management, Economics and Commerce, 3(3), 202-24, 2012.

[24] P. Kotler and G. Armstrong. "Principles of Marketing, $14^{\text {th }}$ Edition", Pearson Prentice Hall, Boston, New York, 2011.

[25] A. A. Lazarus. "Multinational Corporations". International Encyclopedia of the Social \&Behavioral Sciences. Vol. 7 No. 3, 2001

[26] M. J. Lebas. "Performance Measurement and Performance Management". International Journal of production economics. Vol. 41, Issues 1-3, Pages 23-35, 1995.

[27] J. W. Lu and P.W. Beamish. "The internationalization and performance of SMEs". Strategic management journal, 22(6-7), 565586,2001

[28] H. Mejlumyan. "Performance of multinational company", Unpublished Diploma Thesis, Masaryk University, 2016.

[29] K. E. Meyer, S. Estrin, S. K. Bhaumik, and M. W. Peng, "Institutions, resources, and entry strategies in emerging economies", Strategic management journal, 30(1), 61-80, 2009.

[30] M. Madanoglu and E. Karadag. "Corporate governance provisions and firm financial performance: The moderating effect of deviation from optimal franchising". International Journal of Contemporary Hospitality Management, 28(8), 1805-1822. 2016.

[31] M. Madang, K. Lee, and G. J. Castrogiovanni, "Franchising and firm financial performance among US restaurants". Journal of Retailing, 87(3), 406-417, 2011.

[32] L. Mokamba. "The influence of psychic distance and knowledge management on the relationship between firm competencies and performance of multinational corporations in Kenya". Unpublished Ph.D. Dissertation of the University of Nairobi. 2016.

[33] N. A. Morgan, A. Kaleka and C.S. Katsikeas. "Antecedents of export venture performance: A theoretical model and empirical assessment". Journal of marketing, 68(1), 90-108. 2004.

[34] A. Neely. "Business performance measurement: Unifying theory and integrating practice". 2nd edition, Cambridge University Press. 2011.

[35] L. Ndegwa and K. Otieno. "Market entry strategies for a transition country, Kenya: A case study of yitoyj". Unpublished Degree Programmed Thesis of Larea University. 2010.

[36] M. Nippa, S. Beechler and A. Klossek. "Success Factors for Managing International Joint Ventures: A Review and an Integrative Framework". Management and Organization Review Vol 3 No 2 pp 277-310. 2007.

[37] B. Nisha. "Foreign market entry strategies". International Journal of All Research Education and Scientific Methods, 4 (1), 20-23. 2016.

[38] B. M. Oviatt, and McDougall, P. P. McDougall, "Defining international entrepreneurship and modeling the speed of internationalization", Entrepreneurship Theory and Practice, 29(5), 537-553, 2005.

[39] R. B. Robinson. "The Importance of "Outsiders" in Small Firm Strategic Planning". The Academy of Management Journal. Vol. 25, No. 1 (Mar., 1982), pp. 80-93. 1982.

[40] F. Root. "Entry strategies for International Markets". Jossey-Bass book, New York. 1994.

[41] P.E. Sanchez and B. J. Pla "Multidimensional concept of uncertainty and its influence on the entry mode choice: An empirical analysis in the service sector". International Business Review. Vol. 15. pp. 215-232. 2006.

[42] K. Shaw. "Foreign Market Entry Strategies". China-USA Business Review, August 2015, Vol. 14, No. 8, 395-398. 2015.

[43] D.A. Singh. "Export performance of emerging market firms", International Business Review, 18, 321-330. 2009. 
[44] W. Sukali, “International Market Entry Strategies Organizational Characteristics and the Performance of Manufacturing firms in Kenya". Unpublished Master's Thesis of University of Nairobi, 2013.

[45] D. Tan. "Foreign market entry strategies and post-entry growth: Acquisitions vs Greenfield investments". Journal of International Business Studies, 40(6), 1046-1063. 2009.

[46] C. R. Taylor, S. Zou and G. E. Osland. "Foreign market entry strategies of Japanese MNCs". International Marketing Review, 17(2), 146-163. 2000.

[47] M. Theodosiou, and L. C. Leonidou, "Standardization versus adaptation of international marketing strategy: an integrative assessment of the empirical research". International Business Review, 12(2), 141-171, 2003.

[48] A. Verbeke and L. Kano. "An internalization theory rationale for MNE regional strategy". Multinational Business Review, 20(2), 135-152. 2012.

[49] P. Westhead, D. Ucbasaran and M. Wright. "Information search and opportunity identification: The importance of prior business ownership experience"'. International Small Business Journal 27(6): 659-680. 2009.

[50] P. Westhead, D. Ucbasaran and F. Martin. "International market selection strategies of manufacturing and services firms". Entrepreneurship \& Regional Development, 13(1), 17-46. 2001.

[51] P. Westhead, D. Ucbasaran and M. Wright. "International market selection strategies selected by 'micro'and 'small'firms". Omega, Elsevier, vol. 30(1), pages 51-68. 2002.

[52] N. J. Wulf. "Empirical Research on Foreign Entry Market Mode". Unpublished Ph.D. Dissertation of Arhus University, Denmark. 2015

[53] S. A. Zahra, R. D. Ireland and M. A. Hitt. "International expansion by new venture firms: International diversity, mode of market entry, technological learning, and performance". Academy of management Journal, 43(5), 925-950. 2000.

[54] H. Zhao and C-C Hsu. "Social Ties and Foreign Market Entry: An Empirical Inquiry”. Management International Review. Vol. 47, No. 6 (2007), pp. 815-844. 2007.

[55] J. Zekiri and B. Angelova. "Factors that Influence Entry Mode Choice in Foreign Markets". European Journal of Social Sciences - Volume 22, Number 4, 572. 2011

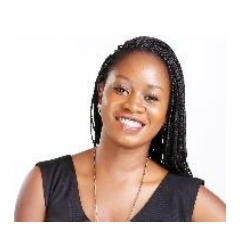

Smith C. was born in Siaya County, Kenya on the 9th of January 1985. She obtained her Bachelor of Commerce and MBA degree in International Business Management from the University of Nairobi and is currently a Ph.D. Candidate in Global Business Management at the same university. Christine earned her Bachelors in 2008 and her MBA degree in 2011. She hopes to obtain her doctorate in December 2021. She is also an experienced academic coach in undergraduate and postgraduate modules; (Research Methods, Strategic Management, Market Research and Analytics and Principles of Management). Currently, she is teaching Business English with Boderlink in Osaka, Japan. Before that, she worked on a part-time basis as an ACADEMIC TUTOR for UNICAF University from February 2018 to May 2021. Prior to Unicaf, from 2014 to 2017, she worked for Knod Foundation in partnership with HELP University (Malaysia) and New Charter University (USA) in teaching degree programs. Before joining academia, she worked at Standard Chartered Bank as an OPERATIONS GRADUATE OFFICER and Barclays Kenya as an INTERNATIONAL TRADE SPECIALIST from 2009 to 2014 and 2015 to 2016 respectively. Christine was awarded for being the best performing candidate in Absa's Management Trainee Programe Summit held in Johannesburg in South Africa in 2016.

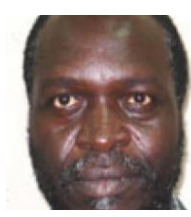

Ogutu M. was born in Kenya on the $6^{\text {th }}$ of July 1952 The co-author obtained his Bachelor of Education, Master of Business Administration, both from the University of Nairobi, Kenya and Doctor of Philosophy in Business Administration from Soka University in Tokyo, Japan. Ogutu earned his Bachelors in 1978, MBA 1983, and Ph.D. degree in 1994

$\mathrm{He}$ is an ASSOCIATE PROFESSOR at the University of Nairobi in the department of Business administration, a title and position he obtained on January $25^{\text {th }} 2012$. He also served as the PHD PROGRAM COORDINATOR from 2014 to 2019 at the University of Nairobi, School of Business. From 1997-2012, he was a SENIOR LECTURER at the same university and before that, he worked as a GRADUATE ASSISTANT and LECTURER from 1983 to 1997. He underwent a one-week training course at the Centre of Corporate Governance in Kenya in the year 2011. He also attended training of trainer's course in Arusha, Tanzania in 1988. His main field of research is general management and strategic management.

Prof. Ogutu is a Board Member of Nyahera Secondary School since 2016, Kachieng' Secondary from 2015 to date and Kalando Secondary School from 2013 to 2015. His publications include:

1. Odhiambo M.A., Kaijage E.S., Iraya C. and Ogutu M. (2018). Board Activities and Performance of Firms Listed at the Nairobi Securities Exchange. European Scientific Journal, Vol. 14, No. 28, 250-269.

2. Ndung'u C., Ogutu M., Yabs J. and Njihia J.M. (2018) The Joint Effect of Competitive Strategies, Business Environment and Corporate Image on Performance of Large Manufacturing Firms in Kenya. Journal of Economics and Business, Vol. 1, No.2, 164-170.

Professor Ogutu was awarded for being the best B.Ed. Business Education Grandaunt, 1978, Kenyatta University, which was a constituent college of the University of Nairobi at that time.

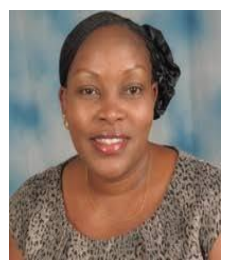

Munjuri M. was born in Kenya on the $2^{\text {nd }}$ of July 1973. The co-author obtained her Bachelor of Education from Kenyatta University, Kenya in 1997, Master of Business Administration from the University of Nairobi, Kenya in 2004, and Ph.D. degree from the University of Nairobi, Kenya in 2013. Her area of specializations is in human resource management.

She is a SENIOR LECTURER at the University of Nairobi, Kenya in the department of Business administration, a title she is held since 2019. She was also a LECTURER between September 2014 to October 2019 and a TUTORIAL FELLOW from October 2012 to August 2014 from the same university. She worked for the United Nations as an ASSISTANT TRAINING COORDINATOR and ASSISTANT HUMAN RESOURCE CONSULTANT from January 2005 to September 2005. From August 2006 to October 2012, she worked as an ASSISTANT LECTURER at the Catholic University of Eastern Africa. Research interests are in performance management, training and development, employee empowerment and separation.

Dr. Munjuri is a member of Higher Education Academy in the United Kingdom, MBA Alumni Association and York St. John University Alumn Association. Her Publications include:

1. Munjuri M. G. (2011), "A survey of the criteria used by commercial banks in Kenya to determine employees to retrench", International Journal of Business Administration, Vol 2, No. 2, pp 57-81.

2. Munjuri M. G. (2018), "Human Capital, Quality of Decisions and Performance of Commercial Banks and Insurance Firms in Kenya", International Journal of Arts and Commerce, Vol. 7(3), pp. 49-64.

Dr. Munjuri's papers that have been presented in conferences include but not limited to; A review of the factors affecting career advancement and Human Capital and Performance of Commercial banks and Insurance Companies in Kenya.

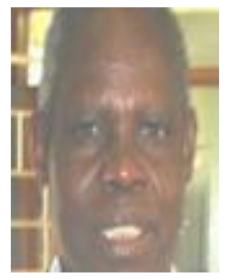

Kagwe J. was born in Kenya. The co-author obtained his Bachelor of Arts from the University of Dar es Salaam, Tanzania, Bachelor in Economics from the University of Nairobi, Kenya, Master of Business Administration from York University in Canada, and $\mathrm{Ph} . \mathrm{D}$. degree from the University of Nairobi, Kenya. His area of specializations is in organization theory and behavior.

$\mathrm{He}$ is a SENIOR LECTURER at the University of Nairobi in the department of Business Administration, a title he is held since 1988. He also served as the SENIOR PROJECTS OFFICER in DFCK from 1978 to 1988 before joining the University. Between 1990 and 1997, he was the COORDINATING WADEN at the University of Nairobi in the Lower Kabete Campus. He was also involved in several road projects with the Kenyan Ministry of Roads to which he conducted sector and socio-economic analysis for different road projects in different parts of the country including but not limited to Isiolo, Bungoma and Machakos. His research interests largely lie in matters to do with banking and cooperative societies.

Dr. Kagwe was a member of Financial Projections and Plans Committee of UNES Income Generating Projects in 1996. In 1990, he participated as a resource person in a seminar of senior Central Bank Officials from Eastern, Central and Southern African Countries. His publications include a proposal on Industrialization in Kenya by the year 2020" in Banking Times Vol.2 1995 and a handbook on African Banking systems titled Management of Organizations in Africa. 